\title{
Effect of Cytokines On The In Vitro of Sweet Kaffir Lime (Citrus hystrix Dc)
}

\author{
Rd. Selvy Handayani*1, Ismadi Yunus', Nadia Tillah1, Ira Handayani2 \\ ${ }^{1}$ Department of Agroecotechnology, Faculty of Agriculture, Universitas Malikussaleh, Aceh Utara, Indonesia \\ 2Postgraduate Student, Department of Agroecotechnology, Faculty of Agriculture, Universitas Malikussaleh \\ Reuleut Campus, Muara Batu, Aceh Utara 24355, Indonesia \\ *Corresponding author: selvy@unimal.ac.id
}

\section{ARTICLE HISTORY}

Received : 13 July 2020

Revised : 22 August 2020

Accepted : 24 September 2020

\section{KEYWORDS}

$B A P$;

Bud;

Explant;

Sterilization;

\begin{abstract}
Sweet kaffir lime (Citrus hystrix Dc), also called "Boh Kruet Mameh" is one of Aceh's local plants, which is currently very difficult to obtain. Sweet kaffir lime is not like the ordinary kaffir lime, which tastes sour. The fruit of sweet kaffir lime has a larger size than the regular kaffir lime, sweet and sour taste, aromatic and fresh, which can be consumed as a fruit table. The problem of developing the propagation technique of sweet kaffir lime plants is the seeds' condition, which are conventionally difficult to germinate and limited in number, making it difficult to get a high-quality seed. Thus, to overcome these problems, suitable solutions to plant propagation techniques should be sought. As for the right plant propagation technique is tissue culture technology or in vitro propagation technique. This research was conducted at the Plant Tissue Culture Laboratory, Faculty of Agriculture, Malikussaleh University. The research was conducted from February to April 2018. This research used a single randomized complete design (CRD) with ten replications. The treatment is a combination of the basic media, which consists of MS0 (MS media without BAP) and MS1 (MS + BAP $4 \mathrm{ppm}$ ). The result showed that the adduction of $4 \mathrm{ppm}$ BAP in MS media influenced the in vitro sweet kaffir lime seeds' growth. Sweet kaffir lime seeds that were given 4 ppm BAP grew buds faster with more percentage of shoot growth, the number of shoots, and a number of leaves than the seeds without BAP adduction.
\end{abstract}

\section{INTRODUCTION}

Indonesia is a mega biodiversity country. The advancement of civilization and the increasing human population is one of the causes of habitat loss in biodiversity and decreased the number of living species every year. It is estimated that $20-50 \%$ of species will become extinct in the next century if there is no conservation effort (Sutarno \& Setiawan, 2015). This also happened in Indonesia, especially in the Province of Aceh, which also experienced a genetic resource crisis; therefore, efforts are needed to preserve some endangered species.

Sweet kaffir lime (Citrus hystrix Dc), also called "Boh Kruet Mameh" is one of Aceh's local plants, which is currently very difficult to obtain. Sweet kaffir lime is not like the ordinary kaffir lime, which tastes sour. The fruit of sweet kaffir lime has a larger size than the regular kaffir lime, sweet and sour taste, aromatic and fresh, consumed as a fruit table. Sweet kaffir lime plants can live more than 40 years with a reasonably low crop production of only 50-70 fruit per season (Mirza, 2015).

Cultivation of sweet kaffir lime plants is almost no longer practiced because people have begun to switch to plants of high economic value, such as oil palm and areca nut. Its existence is starting to disappear, causing people, in general, are not familiar with this fruit plant. Sweet kaffir lime is a precious asset in Indonesia's biodiversity; thus, it needs to be preserved to prevent extinction. Therefore it is necessary to make various efforts to protect plants, including plant propagation techniques. Developing the propagation technique of sweet kaffir lime plants is the seeds' condition, which is conventionally difficult to germinate and limited in number, making it difficult to get a high-quality seed (Mirza, 2015). Thus, to overcome these problems, suitable solutions to plant propagation techniques should be sought. As for the right plant propagation technique is tissue culture technology or in vitro propagation technique.

Tissue culture is a method of isolating plant parts and growing them on media containing nutrients in aseptic conditions, therefore that the plant parts can regenerate into complete plants. Plant tissue culture can be interpreted as a method of artificial vegetative propagation by isolating plant parts in organs, tissues, cells, or protoplasts, to be grown on media that contains nutrients (Wijayanti, et al., 2015). This activity is carried out in a sterile and controlled environment so that the plant parts can grow and differentiate into complete plants. Plant tissue culture techniques have been carried 
out to preserve rare plants, plants that are difficult to propagate conventionally, and support plant biotechnology programs. Various important plants have been successfully propagated through tissue culture, including Kalimantan Lai durian plants (Kurniadinata \& Prayudhiani, 2012), tiger orchids (Isda \& Fatonah, 2014), mangosteen (Handayani et al., 2013; Handayani et al., 2018; Agustina, et al., 2020), and pamelo (Handayani, et al., 2020a; Handayani, et al., 2020b). One of the successes of tissue culture propagation is determined by plant growth regulators (PGR), which is given to the base media. The use of PGR is adjusted to the desired direction of explant growth (Akbar et al., 2017). Cytokines is used to stimulate shoot formation in cultured explants (Rasud, et al., 2015).

Sweet orange (Citrus sinensis), which has been given 1 $\mathrm{mg} / \mathrm{L}$ BAP, results in faster bud formation (Rasud, et al., 2015). The effect of BAP concentration on the initiation of shoot growth starting from the age of seven to fourteen days with a concentration of $3 \mathrm{mg} / \mathrm{L} \mathrm{BAP}$ resulted in the highest bud formation and shoot height in Kina explant (Santoso \& Nursandi, 2003). Moreover, the addition of 4 ppm BAP in clove explants caused the best shoot to appear, the best number of shoots, and the best percentage of shoot growth (Haris, et al. 2013). This research discusses the effect of cytokine addition on the in vitro propagation of sweet kaffir lime plants. The success of this research is very beneficial for society, education, plant breeding, and protection of plant genetic resources.

\section{MATERIALS AND METHODS}

\subsection{Place and Duration}

This research was conducted at the Plant Tissue Culture Laboratory, Faculty of Agriculture, Universitas Malikussaleh, from February to April 2018. The materials used in this research were sweet kaffir orange seeds from Tangse (Pidie Regency), distilled water, alcohol, fungicide and bactericide, disinfectant Bayclin, sterile paper, sugar, agar, liquid detergent, clear plastic, plastic wrap, tissue rolls, The success of in vitro seed germination of sweet kaffir lime can be seen from the data based on the observations that have been made. In the first week, explants treated by 4 ppm MS + BAP showed a good response compared to explants on MS media without BAP. This can be seen from the germination of sweet kaffir lime, which is faster by giving 4 ppm BAP compared to MS0. Observations are carried out until week 8 . From the observations made, it showed that the explants of sweet kaffir lime planted on MS0 media without the addition of growth regulators as well as the explants on 4 ppm MS + BAP media showed a good growth response. Each treatment shows a different effect on the growth of explants. The emergence of shoots characterizes explant growth. The growth of shoots in explants shows that planted explants can regenerate, supported by the availability of nutrients that can be absorbed by explants in the media. Results of the
MS basic media (Murashige \& Skoog), BAP (benzil amino purine), and sterile aquadest. The types of equipment used are LAFC (laminar airflow cabinet), autoclave, oven, bunsen, petri dish, tweezers, scalpel, culture bottles, analytical scales, magnetic stirrers, hotplates, chemical beakers, measuring flasks, measuring cups, cameras, and stationary.

\subsection{Research Methods}

This research used a single Randomized Complete Design (CRD) with ten replications. The treatment is a combination of the basic media, which consists of MS0 (MS media without BAP) and MS1 (MS + BAP 4 ppm). Sweet kafir lime seeds were peeled first, and then it was soaked in $20 \%$ of disinfectant solution for 20 minutes while occasionally being shaken. The seeds were soaked in the solution twice. The seeds were then rinsed with sterile distilled water three times. After being rinsed, these seeds were soaked in distilled water and stored in the refrigerator for a week. The seeds were needed to be drained on sterile paper in petri dishes before using. Sterile seeds were cut into two parts and planted on media, four explants per glass jar. The culture jar should be tightly closed, wrapped in order to avoid contamination. The jars were then stored in an incubation chamber with temperatures ranging from $24-26^{\circ} \mathrm{C}$.

\subsection{Variables Observed}

Variables observed were the percentage of shoot growth, shoot growth time, number of shoots, and number of leaves.

\subsection{Data Analysis}

The data obtained were analyzed using Analysis of Variance. If significant different results are obtained, further tests are carried out using the least significant difference test (LSD) with 5\%.

\section{RESULTS AND DISCUSSIONS}

\subsection{Results}

analysis of variance showed that there were significant differences between the treatments given to the observed variables. Explants planted on 4 ppm MS + BAP media showed better growth and development of shoots than using MS0 media. The percentage of shoot growth is the success rate of growing and developing explants after being planted in the media. The observation on the percentage of successful shoots growth of the sweet kaffir lime (Citrus hystrix Dc) to the addition of cytokines in vitro at the age of 1-8 weeks after planting can be seen in Table 1. 
Table 1. The percentage of shoot growth in sweet kaffir lime seeds explants by the addition of cytokines in vitro.

\begin{tabular}{lcccccccc}
\hline & \multicolumn{1}{c}{ Weeks } \\
\cline { 2 - 7 } \multicolumn{1}{c}{ Treatments } & 1 & 2 & 3 & 4 & 5 & 6 & 7 & 8 \\
\hline \multirow{2}{*}{ MS0 } & $-1 .-11 \mathrm{a}$ & $66.67 \mathrm{~b}$ & $66.67 \mathrm{~b}$ & $68.75 \mathrm{a}$ & $68.75 \mathrm{a}$ & $63.89 \mathrm{~b}$ & $63.89 \mathrm{~b}$ & $63.89 \mathrm{~b}$ \\
MS+BAP 4 ppm & $61.16 \mathrm{a}$ & $90.00 \mathrm{a}$ & $92.50 \mathrm{a}$ & $92.50 \mathrm{a}$ & $91.67 \mathrm{a}$ & $91.67 \mathrm{a}$ & $94.44 \mathrm{a}$ & $94.44 \mathrm{a}$ \\
\hline
\end{tabular}

Figures followed by the same letters in the same column do not differ significantly as determined by Least Significant Difference Test (LSD) level of $5 \%$.

Based on Table 1, it can be seen that the explants of sweet kaffir lime planted on 4 ppm MS + BAP media showed the percentage of shoot growth was better than MS treatment without BAP. From the observations made, the treatment of media composition significantly affected the time of sweet kaffir lime seeds germination. The shoot growth time variables showed that the BAP addition in MS media affected the shoot growth time.

The results of further tests for time variables of the shoot and root growth on kaffir lime seeds explants are presented in Table 2.

Table 2. Time of shoot growth, the number of shoots, and the number of leaves on the germination of sweet kaffir lime seeds explants by the addition of cytokines in vitro

\begin{tabular}{ccc}
\hline Treatment & $\begin{array}{c}\text { Time of shoots } \\
\text { growth (DAP) }\end{array}$ & $\begin{array}{c}\text { Time of root } \\
\text { growth (DAP) }\end{array}$ \\
\hline MS0 & $9.53 \mathrm{~b}$ & 4.65 \\
MS+BAP 4 ppm & $7.74 \mathrm{a}$ & 3.38
\end{tabular}

Figures followed by the same letters in the same column do not differ significantly as determined by Least Significant Difference Test (LSD) level of $5 \%$.

Based on Table 2, it can be seen that only the time of shoots growth of in vitro sweet kaffir lime seeds with the addition BAP showed influence. The $4 \mathrm{ppm}$ BAP treatment causes the seeds to germinate faster. The analysis of variance showed significant differences between the treatments given to the number of shoots and the number of leaves. The observation of the number

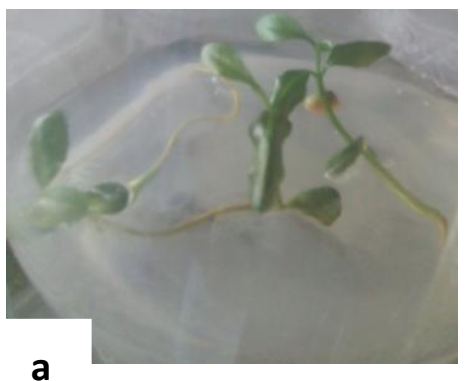

of shoots and the number of leaves of the sweet kaffir lime to the addition of cytokines in vitro can be seen in Table 3.

Table 3 described the number of shoots and leaves of in vitro sweet kaffir lime seeds with the addition of BAP showed an influence. 4 ppm BAP treatment caused the seeds to produce more shoots and leaves. The number of shoots is one of the most important variables to observe because the more shoots grow, the higher the chance of successful growth shown by the explants. Results of the observation and analysis of variance showed a significant influence of the use of MS0 and $4 \mathrm{ppm}$ MS + BAP media on the number of shoots produced by the explants. In vitro sweet kaffir lime shoots that grow 8 WAP are presented in Figure 1.

Table 3. The number of shoots and the number of leaves on the germination of sweet kaffir lime seeds explants by adding cytokines in vitro.

\begin{tabular}{ccc}
\hline Treatments & Number of shoots & Number of leaves \\
\hline MS0 & $1.26 \mathrm{a}$ & $3.49 \mathrm{~b}$ \\
MS+BAP 4 ppm & $2.24 \mathrm{a}$ & $7.37 \mathrm{a}$ \\
\hline
\end{tabular}

$\overline{\text { Figures followed by the same letters in the same column do not differ }}$ significantly as determined by Least Significant Difference Test (LSD) level of $5 \%$.

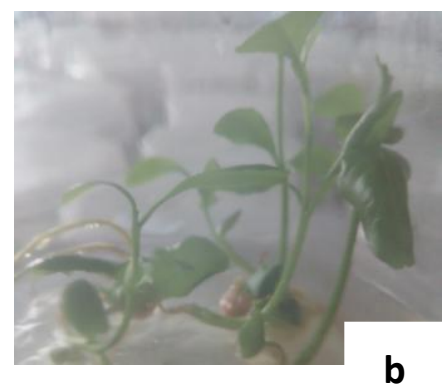

Figure 1. In vitro sweet kaffir lime shoots grown at 8 WAP. (a) on MS0 media; (b) on 4 ppm MS+BAP media

From Figure 1, it can be seen that there were differences in the growth of in vitro sweet kaffir lime shoots. In vitro sweet kaffir lime shoots that grow on $4 \mathrm{ppm}$ BAP treatment have more shoots than without BAP treatment.

\subsection{Discussions}


Based on the experiments conducted, it can be seen that the application of BAP growth regulators to MS media with a concentration of $4 \mathrm{ppm}$ has no significant effect on the growth of sweet kaffir lime shoots produced. This can be seen from all observed variables (Table 1.). BAP is one of the cytokines that can encourage the division of meristemic cells so that the shoots can form leaves better.

A good percentage of explant growth is due to the availability of nutrients, insufficient growth media. The high percentage of explant life also depends on the condition of the explant; the explants used from the actively splitting tissues and are supported by the type and composition of the media, and the use of plant growth regulators with the right concentration will increase the growth in plants (planted explants). In contrast, a higher concentration can inhibit plant growth; the use of high concentrations can also poison or even kill plants. The application of plant growth regulators for plant growth success can be determined by several factors, including the precise concentration used, the method of treatment on plants (explants), the time of PGR addition, and the right combination.

According to George \& Sherington (1984), the addition of growth regulators in the media is one factor that significantly influences the success of tissue culture. In general, in vitro propagation using plant growth regulators from the cytokine group is widely used to stimulate the formation of shoots, which actively encourage cells' formation.

The observations on MS0 media showed that the planted explants showed a very slow growth compared to the explants with 4 ppm MS + BAP, which showed a faster growth rate. This is because the composition of the media used does not support explants for cell division. The results of 4 ppm MS + BAP media showed no significant difference in the shoot growth time. Based on (Table 3) it can be concluded that the percentage of shoot growth of the sweet kaffir lime seeds in MS0 media reached 9.53 DAP, and 4 ppm MS + BAP reached 7.74 DAP. This shows that cytokines' concentration affected the growth time of shoots in 4 ppm MS + BAP media is faster than MS0.

The composition of plant growth regulators and the media can determine the growth rate of kaffir sweet lime shoots. The use of BAP growth regulators is very effective for stimulating the formation of the shoot. This is supported by Taiz \& Zeinger (2010) statement, which says that cytokines are PGR that encourage cell division (cytokinesis). Cytokine stimulates the division of mitosis in the internal meristem. The increase in the division accelerates the formation of transport tissues on the side shoots to get metabolized energy. Furthermore, Yusnita (2003) stated that cytokine PGR could stimulate the growth of adventitious shoots branching, which is the development of organs such as shoots originating from one growing point.

The observations results show that there are a number of shoots in the explants using 4 ppm MS + BAP, and it increases from week to week. Many of the shoots formed are due to the exogenous growth regulators that reach the explan to stimulate new shoots. This is because to produce shoots in large quantities also comes from the shoots themselves so that the explants used can be more active in responding to the growth regulators (Sumiasri \& Priadi, 2002).

The results of the 5\% LSD test showed that the number of leaves that developed in the 4 ppm MS + BAP treatment was higher and increased from week to week; this can be seen from (Table 6.). Many leaves are also affected by a large number of shoot formation produced because the media used enough nutrients needed by the explants, which stimulate the appearance of shoots and leaves. This is due to the development of in vitro explants and organ formation caused by the nitrogen content in the base media. The addition of appropriate plant growth regulators can increase cell division activity in the process of morphogenesis and organogenesis (Hartmann, et al., 2002).

Contamination can occur in explants with various microorganisms such as bacteria, fungi, and viruses. These bacteria are universally found in plant tissues. Many are non-pathogenic; that is, they do not cause harm to host plants under normal conditions. Contamination is caused by fungi or bacteria that grow on the media's surface (Raynalta \& Sukma, 2013).

Contamination of cultured plant material can occur due to an internal or external infection. Efforts to prevent internal infection are carried out by surface sterilization on the plant material. Internal infections are not eliminated by surface sterilization (Widiastoety, 2001). Imperfect bottle washing can cause bacterial or fungal contamination in the bottle surface; usually, several weeks or months after the media is sterilized (Yuliarti, 2010).

\section{CONCLUSION}

The application of 4 ppm BAP in MS media influenced the growth of the in vitro sweet kaffir lime seeds. The seeds treated with 4 ppm BAP grew faster with more shoot growth, the number of shoots, and a number of leaves than the untreated seeds.

\section{ACKNOWLEDGEMENTS}

We are sincerely thankful to the Asian Development Bank (ADB) for providing us the funds to conduct this valuable research.

\section{REFERENCES}

Agustina, M., Maisura, M., \& Handayani, R. S. (2020). The Effect of Different Seed Cutting Treatments and Concentrations of BAP for the Successful In Vitro Micrografting of Mangosteen (Garcinia mangostana L.). Journal of Tropical Horticulture, 3(1), 1-5.

Akbar, A. M., Faridah, E., Indrioko, S., \& Herawan, T. (2017). Induksi tunas, multiplikasi dan perakaran Gyrinops versteegii (Gilg.) Domke secara in vitro. Jurnal Pemuliaan Tanaman Hutan, 11(1), 155-168.

George, E. F., Hall, M. A., \& De Klerk, G. J. (Eds.). (2007). Plant propagation by tissue culture: volume 1. the background (Vol. 1). Springer Science \& Business Media. 
Handayani, R. S., Poerwanto, R., Purwito, A., \& Ermayanti, T. M. (2013). Pengaruh Batang Bawah dan Jenis Tunas pada Mikrografting Manggis (Garcinia mangostana) secara In Vitro. Jurnal Agronomi Indonesia (Indonesian Journal of Agronomy), 41(1).

Handayani, R. S., Maisura, M., \& Rizki, A. (2018). Pengaruh Letak Posisi Eksplan dan Sitokinin Pada Perkecambahan Biji Manggis (Garcinia mangostana L.) Lokal Aceh Secara in-Vitro. Jurnal Agrium Unimal, 14(2), 1-8.

Handayani, I., Nazirah, L., \& Handayani, R. S. (2020a). The Effect of BAP and IBA on In Vitro Root Cultures of Acehnese Pomelo (Citrus maxima (Burm.) Merr.). Journal of Tropical Horticulture, 3(1), 38-42.

Handayani, I., Nazirah, L., Ismadi, I., Rusdi, M., \& Handayani, R. S. (2020b) Pengaruh Konsentrasi Bap Pada Perkecambahan Biji Pamelo Asal Aceh Secara In-Vitro. Jurnal Agrium Unimal, 17(2).

Haris, A., Basri, Z., \& Bustami, M. U. (2013). Inisiasi Tunas Cengkeh (Syzigium Aromaticum L.) Dengan Berbagai Konsentrasi Bap Secara in Vitro. Agrotekbis, 1(4).

Hartmann, H. T., Kester, D. E., Davies, F. T., \& Geneve, R. L. (2002). Plant propagation, principles and practices. Prentice upper saddle river-Hall. Iac, New Jersey.

Isda, M. N., \& Fatonah, S. (2014). Induksi Akar pada Eksplan Tunas Anggrek Grammatophylum scriptum var. citrinum secara In Vitro pada Media MS dengan Penambahan NAA Dan BAP. Al-Kauniyah: Jurnal Biologi, 7(2), 53-57.

Kurniadinata, O. F., \& Prayudhiani, Y. (2012). Perbandingan zat pengatur tumbuh auksin dan sitokinin dalam mempengaruhi pertumbuhan stek pucuk tanaman lai (Durio kutejensis) secara in vitro.

Mirza, I. (2015). Karakterisasi Dan Koleksi Sumberdaya Genetik Tanaman Dan Ternak Lokal Di Propinsi Aceh.
Rasud, Y., Ulfa, S., \& Baharia, B. (2015). Pertumbuhan jeruk manis (Citrus sinensis L.) dengan penambahan berbagai konsentrasi sitokinin secara in vitro. Agroland: Jurnal Ilmu-ilmu Pertanian, 22(3), 197-204.

Raynalta, E., \& Sukma, D. (2013). Pengaruh komposisi media dalam perbanyakan protocorm like bodies, pertumbuhan planlet, dan aklimatisasi Phalaenopsis amabilis. Jurnal Hortikultura Indonesia, 4(3), 131-139.

Santoso, U., \& Nursandi, F. (2003). Kultur jaringan tanaman. Universitas Muhammadiyah Malang, Malang, 191.

Sumiarsi, N., \& Priadi, D. (2002). Pengaruh Zat Pengatur Tumbuh BAP terhadap Pertumbuhan Stek batang Sungkai (Peronema cunescens Jack) pada Media Cair. Jurnal Alam, IX (2): hal, 32-37.

Sutarno, S., \& Setyawan, A. D. (2015). Genetic diversity of local and exotic cattle and their crossbreeding impact on the quality of Indonesian cattle. Biodiversitas Journal of Biological Diversity, 16(2).

Taiz, L., \& Zeiger, E. (2010). Plant Physiology. 5th Edn ed. Massachusetts: Sinauer Associates.

Widiastoety, D. (2001). Perbaikan genetik dan perbanyakan bibit secara in vitro dalam mendukung pengembangan anggrek di Indonesia. Jurnal Litbang Pertanian, 2(4), 138-143.

Wijayanti, I., Isda, M. N., \& Lestari, W. (2015). Induksi Akar Jeruk Siam Asal Kampar (Citrus Nobilis Lour.) Dari Tunas in Vitro Dengan Berbagai Kombinasi Sukrosa Dan Naa Pada Media 1/2 Murashige and Skoog (Doctoral dissertation, Riau University).

Yuliarti, N. (2010). Kultur Jaringan Tanaman Skala Rumah Tangga. Penerbit Andi

Yusnita (2003) Kultur Jaringan: Cara Memperbanyak Tanaman Secara Efisien. Penerbit Agromedia Pustaka. 